\title{
IMPLEMENTASI PERFORMANCE BASED ASSESSMENT DALAM PEMBELAJARAN EKONOMI
}

\author{
${ }^{1}$ Ekayanti Nur Anix, ${ }^{2}$ Fifi Fauziyah \\ 1,2 Pascasarjanah Pendidikan Ekonomi Universitas Pendidikan Indonesia \\ Ekayantinuranix@upi.edu
}

\begin{abstract}
ABSTRAK
Abad ke-21 adalah abad yang meminta kualitas dalam segala usaha dan hasil kerja manusia. Pembangunan sumber daya manusia berkualitas dalam ilmu pengetahuan dan teknologi melalui lembaga pendidikan merupakan pilar penting untuk mewujudkan visi Indonesia 2015-2085. Peran guru pada kegiatan pembelajaran sangat penting untuk membangun sumber daya manusia memiliki keterampilan abad 21. Performance Based Assessment sebagai model yang mengombinasi pengajaran dan penilaian, tepat diterapkan dalam pembelajaran untuk mengembangkan kompetensi critical and creative thinking serta dapat mengukur kemampuan kognitif, afektif dan psikomotor.

Pada proses pembelajaran ekonomi, guru cenderung memfokuskan pada proses kognitif, siswa jarang dituntut untuk menunjukkan kinerjanya sehingga hanya beberapa siswa yang aktif dalam proses pembelajan. Oleh karena itu, penggunaan Performance Based Assessment penting diterapkan pada pembelajaran ekonomi, karena dapat melatih kinerja siswa, meningkatkan kemampuan inquiry, keterampilan dan kebiasaan kerja melalui tugas secara nyata. Siswa diharapkan aktif berpikir, melakukan penalaran, mengomunikasikan pengetahuan yang dimilikinya dan memecahkan masalah realistik. Penulis menggunakan metode studi pustaka. Tujuan studi pustaka ini adalah mengkaji Performance Based Assessment dan penerapannya pada pembelajaran ekonomi.
\end{abstract}

Kata kunci: Performance Based Assessment, pembelajaran ekonomi, critikal thinking dan creative thinking

\section{ABSTRACT}

The $21^{\text {st }}$ century is a century that asks for quality in all effort and human works. Development of qualified human resources in science and technology through educational institutions is an important pillar to realize vision of Indonesia 2015-2085. The role of teachers in learning activities is very important to build human resources has $21^{\text {st }}$ century skills. Performance Based Assessment as a model that combines teaching and assessment, appropriately applied in learning to develop critical competencies and creative thinking also can measure cognitive, affective and psychomotor abilities. In the economic learning process, teachers tend to focus on cognitive processes, students are rarely required to demonstrate their performance so that only a few students are active in the learning process. Therefore, the use of Performance Based Assessment is important to be applied in economic learning, because it can train student performance, improve the ability of inquiry, skills and work habits through real tasks. Students are expected to actively think, do the reasoning, communicate the knowledge it has and solve realistic problems. The author uses literature study method. The purpose of this literature study is reviewing Performance Based Assessment and its application to economic learning.

Keywords: Performance Based Assessment, economic learning, critical thinking and creative thinking 


\section{PENDAHULUAN}

Pada pembelajaran abad 21 guru perlu untuk mengembangkan siswa pada kompetensikompetensi critikal thinking atau creative thinking (Anderson \& Krathwohl, 2001:63). Guru harus menstimulus siswa untuk memiliki kemampuan menerapkan pengetahuan dan keterampilannya di dunia nyata (Lim \& Griffith, 2011; Lane, 2010 :3).

Pembelajaran pasti berkaitan dengan penilaian yang mengukur kemampuan siswa pada aspek kognitif, afektif dan psikomotor. Sebaiknya penilaian tidak hanya dilakukan pada hasil akhir saja, tetapi proses pembelajaran pun semestinya dilakukan oleh guru. Tetapi proses penilaian yang dilakukan oleh guru cenderung ditekankan pada aspek kognitif yang berupa tes pilihan ganda baik pada Ujian Nasional, ulangan harian, Ujian Kenaikan Kelas dan lainlain (Nurdin, 2017). Berdasarkan masalah tersebut, guru perlu mengembangkan model pembelajaran yang dapat mengukur kemampuan kognitif, afektif dan psikomotor. Performance Based Assessment penting untuk dikaji, karena Performance Based Assessment merupakan model yang mengombinasi pengajaran dan penilaian. Performance Based Assessment tepat diterapkan dalam pembelajaran untuk mengembangkan output pada kompetensi-kompetensi critikal thinking atau creative thinking dan membantu siswa mengembangkan beberapa kemampuan kognitif, afektif dan psikomotor. Performance Based Assessment menilai keterampilan tingkat tinggi dan pemahaman konten lebih dalam berdasarkan kinerja nyata yang didemonstrasikan (Stiggins, 1994; Baron \& Wolf, 1996; Rothman, 1995). Studi pustaka ini membahas hakikat, manfaat dan penerapan Performance Based Assessment pada pembelajaran ekonomi.

\section{LANDASAN TEORI}

\section{Definisi Performance Based Assessment}

Performance Based Assessment merupakan seperangkat strategi untuk menerapkan pengetahuan, keterampilan dan kebiasaan kerja, melalui tugas secara nyata yang bermakna dan menarik bagi siswa pada proses pembelajaran (Hibbard, 1999). Performance Based Assessment merupakan model yang mengombinasikan penilaian dan pengajaran yang akan mengubah situasi statis menjadi dinamis, aktif dan variatif (Epstein, 2006). Berbeda dengan pendapat lain, bahwa Performance Based Assessment merupakan penilaian yang mencakup pengetahuan dan keterampilan dalam dunia nyata (Slavin, 2009), untuk mengetahui penguasaan kemampuan kognitif tingkat tinggi yang mengintregasikan dan menunjukkan pemahaman tentang berbagai subjek (Baker, 1997). Penilaianya dilaksanakan sepanjang proses pembelajaran (Washer \& Cochran, 2012).

Berdasarkan uraian di atas, Performance Based Assessment sebagai strategi pengajaran, agar siswa dapat menerapkan penguasaan pengetahuan dan keterampilan pada situasi nyata, tujuannya untuk menstimulus siswa lebih aktif, memiliki keterampilan dan kemampuan kognitif tingkat tinggi. Performance Based Assessment sebagai penilaian untuk mengukur kemampuan tersebut pada proses pembelajaran.

\section{Karakteristik Performance Based Assessment}

Karakteristik Performance Based Assessment yaitu bersifat intregatif, mengombinasikan strategi pengajaran dan penilaian (Epstein, 2006), bersifat process orientied, tidak hanya mengutamakan hasil (Isa \& Burhanuddin, 2014; Mansur, 2015), lebih menekankan pada persoalan nyata berkaitan dengan kehidupan sehari-hari yang memerlukan berbagai macam pendekatan untuk memecahkan masalah (Airasian, 2005:234), terdiri dari tugas yang bermakna bagi siswa (Brualdi, 1998), menggunakan rubrik penilaian (Lund, 2010), mengukur kemampuan kognitif, afektif dan psikomotor (Guntur, 2014), dan memiliki reliabilitas (Johnson, 2009)

Berdasarkan uraian di atas, karakteristik Performance Based Assessment yaitu terintregasi dalam strategi pengajaran dan penilaian, keduanya merupakan bagian yang tidak terpisahkan. Tugas berorientasi pada kegiatan mendemonstrasikan atau praktik, menggunakan rubrik untuk menilai keterampilan tingkat tinggi dalam memecahkan masalah 
realistis sehingga siswa tidak hanya dituntut untuk memahami, tetapi menganalisis, mengevaluasi dan berkreasi, process oriented, dan hasil kerja siswa, serta memiliki reliabilitas.

\section{Tujuan Performance Based Assessment}

Reformasi ilmu pengetahuan saat ini menuntut siswa lebih aktif terlibat dalam ilmu pengetahuan daripada membaca atau mendengarkan reaktif (Atkin, Black, \& Coffey, 2001). Performance Based Assessment diterapkan dalam situasi kehidupan nyata (Linn, Baker \& Dunbar; 1991), untuk menstimulus siswa terlibat aktif dalam berpikir tingkat tinggi dan melakukan penalaran (Metin \& Ozmen, 2010), mengharuskan siswa untuk menjelaskan dan mengkomunikasikan tentang informasi dan memecahkan masalah (Morrison, McDuffie, \& Akerson, 2002; Suzann, 2000). Selain itu, Performance Based Assessment bertujuan untuk menerapkan kemampuan kognitif melalui kinerja dan mendemonstrasikan inkuiri ilmiah siswa (Muslich, 2011).

Berdasarkan uraian di atas, Performance Based Assessment bertujuan untuk mengaktifkan siswa, seperti siswa harus aktif berpikir, melakukan penalaran, menjelaskan dan akhirnya siswa dituntut untuk mengomunikasikan pengetahuan yang dimilikinya dan memecahkan masalah realistik. Kemampuan tersebut pada dasarnya adalah kemampuan berpikir tingkat tinggi dan berpikir kreatif, yang perlu ditingkatkan untuk membekali siswa menghadapi tantangan dan mengambil peluang pada era globalisasi.

\section{Manfaat Performance Based Assessment}

Performance Based Assessment sebagai strategi pengajaran penting untuk dikembangkan dalam proses pembelajaran, karena dapat menggali potensi serta menilai bakat siswa pada kinerja yang memberikan tantangan siswa berbakat untuk mengungkapkan kapasitas intelektual (Kim, Baska, Bruce, Bracken, Annie, \& Tamra, 2014). Tugas menuntut siswa berbakat dapat memanfaatkan proses berpikir, yang sering diidentifikasi sebagai pusat diferensiasi, seperti membandingkan, mengklasifikasikan, induksi, deduksi, membangun dukungan, abstrak, investigasi, pemecahan masalah, dan penemuan (Marzano, Pickering, \& McTighe, 1993). Performance Based Assessment dinilai tepat diterapkan dalam pembelajaran abad 21 untuk mengembangkan siswa pada kompetensi-kompetensi critikal thinking atau creative thinking dan membantu siswa untuk mengembangkan beberapa keterampilan dalam memecahkan masalah (Anderson \& Krathwohl, 2001:63; Rufina \& Nelson, 2015).

Berdasarkan uraian di atas, Performance Based Assessment sebagai strategi pengajaran dapat memperbaiki sistem pembelajaran saat ini agar lebih produktif dan efektif, karena Performance Based Assessment memiliki banyak kegunaan seperti membantu siswa membangun pengetahuan awal, dapat menggali potensi dan bakat siswa, menekankan siswa untuk lebih percaya diri terhadap kemampuan yang dimiliki, dapat menambah pemahaman siswa tentang apa yang diketahui dan dilakukan, memberikan kesempatan bagi siswa untuk memperlihatkan kemampuannya baik kecepatan maupun ketepatan, dapat menciptakan suasana pembelajaran yang lebih relevan dengan kehidupan, dan meningkatkan motivasi siswa dalam belajar dengan adanya tugas praktik yang realistis dapat mempersiapkan siswa di masa depan yang lebih produktif dalam dunia IPTEK.

Performance Based Assessment sebagai penilaian, berguna untuk mengetahui tentang apa yang siswa ketahui dan tentang apa yang bisa siswa lakukan (Anggreadi, dkk, 2015), mengukur kemampuan siswa dalam mengaplikasikan procedural knowledge, dan pemikiran kritis (Arends, 2004:245), kemampuan metakognitif, menerjemahkan pengetahuan dan pemahaman ke dalam aksi (Airasian, 2005: 234-235). Selain itu, dapat memberikan kesempatan kepada guru untuk mengenali bakat serta kemampuan yang dimiliki oleh siswa yang belum bisa tergambarkan dengan penggunaan tes objektif maupun tes pilihan jamak (VanTassel-Baska, 2013). Performance Based Assessment memberi umpan balik kepada guru untuk memperbaiki lingkungan kelas (Baxter \& Glaser, 1996). Performance Based 
Assessmen digunakan guru untuk memberikan dasar bagi guru untuk mengevaluasi keefektifan proses atau produk dan dapat membimbing sistem pembelajaran agar lebih produktif dan efektif (Oberg, 2000; Linn \& Gronlund, 2000). Sehingga, Performance Based Assessmen tepat untuk diterapkan di era reformasi pendidikan saat ini (Resnick \& Resnick, 1992; Sa'dijah, 2009).

Berdasarkan uraian di atas, Performance Based Assessment dapat mengukur kompetensi critikal thinking atau creative thinking, memberikan gambaran tentang bakat siswa yang berbeda-beda, dan memberikan umpan balik kepada guru untuk memperbaiki lingkungan kelas, memantau ketuntasan belajar dan sebagai alat siswa untuk melakukan evaluasi serta instropeksi. Performance Based Assessment dapat mengukur baik yang tampak sebagai hasil akhir dari suatu proses pembelajaran, maupun berupa perubahan dan perkembangan aktivitas, dan perolehan belajar selama proses pembelajaran.

\section{Komponen Performance Based Assessment}

Performance Based Assessment terdiri dari dua komponen, yaitu tugas dan rubrik (Wren, 2009). Guru memberikan tugas kepada siswa untuk dipraktikan, berdasarkan penguasaan kemampuan kognitif dan keterampilan siswa (Nitko \& Brookhart, 2011). Tugas lebih menekankan siswa pada pemecahan masalah, komunikasi, dan hubungan konsep dengan persoalan dunia nyata (Wiggins, 1998). Tugas dapat berupa suatu proyek, pameran, portofolio, diskusi, presentasi atau tugas-tugas yang mengharuskan siswa memperlihatkan kemampuan kinerja (Muslich, 2011: 70). Tugas harus adil, tidak bias, dapat mengukur kemampuan siswa, instruksinya jelas bagi guru dan siswa, menantang, dapat diselesaikan, bermakna dan menarik bagi siswa, waktunya mencukupi, dan sesuai dengan kompetensi yang hendak dinilai (Wren, 2009). Kemudian tugas dinilai berdasarkan indikator tertentu dengan rubrik (Marhaeni, 2007; Benjamin, 2014).

Rubrik performansi merupakan suatu rubrik yang berisi komponen-komponen suatu performansi ideal, dan deskriptor dari setiap komponen tersebut (Nurdin, 2017). Rubrik merupakan panduan untuk memberi skor yang jelas dan disepakati oleh guru dan siswa (Zainul, 2005:9). Rubrik terdiri dari rubrik analitik dan rubrik holistik. Rubrik analitik yaitu rubrik dengan penyekoran dilakukan dengan membuat pertimbangan secara mandiri pada setiap kriteria secara terpisah dan rubrik holistik yaitu rubrik dengan penyekoran dilakukan dengan membuat pertimbangan secara menyeluruh tentang kinerja yang memadukan seluruh kriteria dalam satu penilaian (Stiggins,1994: 168). Dengan menggunakan rubrik, akan memperbaiki dan memantau kinerja siswa, menggambarkan kekuatan dan kelemahan siswa, dapat mengakomodasi kelas yang memiliki siswa yang heterogen dan membuat guru dan murid bertanggung jawab dan sadar akan tujuan pembelajaran (Morrison, McDuffie \& Akerson, 2005).

Guru tidak hanya mengukur hasil akhir dalam proses pembelajaran, namun dapat mengukur berlangsungnya proses pembelajaran (Sujarwanto \& Ani Rusilowati, 2015). Proses penilaian diamati dan dinilai baik oleh siswa dan guru dengan menggunakan rubrik yang berfokus pada keterampilan (Quiter, 2007).

Berdasarkan uraian di atas, dapat disimpulkan bahwa komponen penting Performance Based Assessment yaitu adanya tugas dan rubrik. Tugas bisa dalam bentuk proyek, pameran, diskusi, portofolio atau tugas-tugas lain yang mengharuskan siswa memperlihatkan kemampuan kinerjanya. Tugas ini akan dinilai oleh rubrik yang memiliki beberapa kriteria dan indikator berkaitan dengan standar penilaian yang seharusnya. Guru dalam proses pembelajaran hanya memfasilitasi dan memotivasi siswa, di samping guru mengamati pekerjaan siswa saat pembelajaran.

Dalam Performance Based Assessment, melibatkan penggunaan berbagai metode mengajar di antaranya metode tanya jawab, metode diskusi, metode pengamatan (observasi), metode simulasi, metode pemecahan masalah, metode pemberian tugas, metode kerja kelompok (Muhson, 2011). 
Menurut Kusmarni (2006) Performance Based Assessment dapat menggunakan berbagai pendekatan seperti: inquiry, cooperative learning, contextual learning, sosio drama, bermain peran, diskusi dan lain sebagainya (Kusmarni, 2006). Langkah-langkah Performance Based Assessment pada proses pembelajaran sebagai berikut:

1. Merancang pembelajaran

Pada tahap merancang pembelajaran meliputi menganalisis kurikulum sebagai pedoman penyelenggaraan kegiatan untuk mencapai tujuan pembelajaran, mengidentifikasi pengetahuan keterampilan yang diharapkan saat/setelah mengikuti kegiatan pembelajaran atau setelah menyelesaikan tugas, merancang model pembelajaran, menetapkan kriteria keberhasilan (rubrik) dan menentukan bentuk instrumen penilaian yang akan digunakan.

2. Melaksanakan pembelajaran

Pada tahap melaksanakan pembelajaran guru memotivasi siswa untuk aktif, guru melakukan pertemuan secara rutin guna mendiskusikan proses pembelajaran yang akan menghasilkan suatu kinerja. Guru menggunakan rubrik penilaian untuk menilai siswa dalam mempresentasikan hasil analisis.

3. Mengevaluasi pembelajaran.

Pada tahap terakhir dilakukan penilaian berdasarkan kriteria penilaian yang disepakati oleh guru dan siswa. Siswa diharapkan menghayati dengan baik kekuatan dan kelemahannya, sehingga hasil penilaian kinerja ini dijadikan tujuan baru bagi proses pembelajaran berikutnya.

\section{Keunggulan dan Kelemahan Performance Based Assessment}

Keunggulan Performance Based Assessment yaitu model yang sesuai untuk mengembangkan kompetensi-kompetensi critikal thinking atau creative thinking (Anderson \& Krathwohl, 2001:63), konsisten dengan teori pembelajaran modern, menghasilkan pembelajaran yang lebih baik, dan membuat pembelajaran lebih bermakna dan memotivasi siswa (Reynolds, dkk., 2010:266), dapat dipertanggungjawabkan dan terbuka (Guntur, 2014). Sedangkan menurut Muslich (2011: 124-125) keuntungan Performance Based Assessment yaitu penilaian pembelajaran yang lebih baik dibandingkan penilaian tes tradisional, menyediakan evaluasi lebih lengkap dan alamiah untuk beberapa macam penalaran, kemampuan lisan, dan keterampilan fisik, guru memiliki metode asesmen yang lebih relevan dan sesuai dengan siswa, guru memiliki cara penilaian yang dapat diadaptasi untuk menilai berbagai bakat dan kemampuan siswa.

Berdasarkan uraian di atas Performance Based Assessment melengkapi penilaian yang hanya dapat memperoleh informasi tentang kemampuan intelektual siswa, karena Performance Based Assessment dapat mengukur keterampilan siswa (aspek psikomotor). Selain itu, Performance Based Assessment tepat untuk melihat sikap siswa yang mencerminkan dalam tingkah laku dalam kehidupan sehari-harinya, dapat dipertanggungjawabkan karena tidak dimanipulasi selama proses penilaian berlangsung dan terbuka karena memiliki peluang untuk klarifikasi bagi siswa untuk menghindari subyektifitas.

Kelemahan Performance Based Assessment yaitu lebih membebani guru karena sangat menuntut waktu dan usaha, serta mempunyai reliabilitas rendah (Nelson \& Rufina, 2015). Berbeda dengan pendapat lain, Performance Based Assessment cenderung pada pertimbangan dan penskoran yang bersifat subyektif dan sulit membuat generalisasi atas keahlian dan pengetahuan siswa (Reynolds, dkk., 2010:267).

Berdasarkan uraian di atas dapat disimpulkan bahwa kelemahan Performance Based Assessment yaitu membutuhkan waktu yang lama dalam mengemas pembelajaran yang berbentuk kinerja. Artinya dalam jumlah siswa yang banyak guru harus mengamatinya satu persatu, memungkinkan juga guru merasa terpengaruh oleh penampilan siswa yang bukan menjadi indikator dalam penilaian, memerlukan pertimbangan tertentu sehingga Performance Based Assessment cenderung subyektif, dan apabila perintah tugas tidak jelas maka tindakan yang muncul tidak sesuai dengan yang diharapkan. 


\section{METODOLOGI}

Penulis menggunakan metode studi pustaka. Studi pustaka menjelaskan hakikat, karakteristik, komponen, tujuan, langkah-langkah, keunggulan dan kelemahan Performance Based Assessment. Penulis mengkaji studi pustaka untuk merancang penerapan Performance Based Assessment pada pembelajaran ekonomi.

\section{PEMBAHASAN}

Performance Based Assessment mengintregasikan aspek penilaian sebagai bagian yang tidak terpisahkan dari proses pembelajaran. Siswa belajar untuk mendapatkan pengetahuan, mengembangkan keterampilan dan mempraktikkan atau mendemonstrasikan penguasaan pengetahuan siswa pada tugas nyata, lalu kinerja dinilai oleh guru dengan alat ukur untuk memberikan informasi pada guru mengenai kemampuan siswa yang dapat dicapai. Manfaanya adalah menstimulus siswa terlibat aktif dalam berpikir tingkat tinggi, melakukan penalaran, melakukan penerapan kemampuan kognitif melalui kinerja dan mendemonstrasikan inkuiri ilmiah siswa.

Nilai lebih dari Performance Based Assessment adalah penilaian pembelajaran yang lebih baik dibandingkan penilaian tes tradisional karena dapat mengukur keseluruhan aspek dan konsisten dengan teori pembelajaran modern. Sesuai dengan prinsip pembelajaran ekonomi bahwa harus memiliki keterkaitan yang erat dan proporsional antara pengembangan aspek kognitif, afektif dan psikomotor yang berkaitan dengan dimensi-dimensi yang dituntut untuk dikembangkan dan dicapai dalam pembelajaran ekonomi.

Performance Based Assessment terdiri dari dua komponen, yaitu tugas dan rubrik. Siswa menunjukkan kinerjanya, lalu guru menilai menggunakan pedoman rubrik penilaian. Guru memfasilitasi untuk menciptakan lingkungan belajar yang baik, membantu siswa merumuskan tujuan belajar, menyediakan sumber belajar, dan mengawasi proses pembelajaran siswa. Guru dan siswa memiliki peran aktif dalam pembelajaran.

Pada pembelajaran ekonomi diharapkan siswa dapat mengembangkan kemampuan untuk memahami berbagai kenyataan dan peristiwa ekonomi yang ada di masyarakat, memahami konsep dan teori, berlatih memecahkan berbagai masalah ekonomi yang ada di masyarakat. Selain itu, diharapkan agar siswa memiliki kemampuan membentuk sikap bijak, rasional dan bertanggungjawan dengan memiliki pengetahuan dan keterampilan ilmu ekonomi, manajemen, dan akuntansi yang bermanfaat bagi diri sendiri, rumah tangga, masyarakat dan negara.

Selain itu, siswa dituntut dapat mengaplikasikan ilmu ekonomi dalam dunia nyata tidak semata pemahaman konsep. Sehingga dibutuhkan sebuah pedoman yang dapat mengarahkan guru untuk mendesain dan mempraktikkan pembelajaran di kelas sesuai dengan tuntutan Kurikulum 2013. Dalam pembelajaran ekonomi harus memudahkan siswa untuk mampu membuat pilihan-pilihan secara rasional dan membuat siswa dapat menggunakan konsep-konsep dalam ilmu ekonomi untuk menganalisis persoalan-persoalan ekonomi personal dan kemasyarakatan. Sehingga, Performance Based Assessment tepat diterapkan dalam membelajarkan siswa untuk mencapai tujuan membangun individu yang memiliki critikal thinking atau creative thinking. Keunggulan performance assessment tersebut bermuara pada peningkatan kualitas pembelajaran.

Hakikat dari Performance Based Assessment adalah strategi untuk menerapkan pengetahuan, keterampilan dan kebiasaan kerja, melalui tugas secara nyata yang bermakna dan menarik bagi siswa pada proses pembelajaran, menuntut siswa untuk menggunakan kemampuan berpikir tingkat tinggi, melakukan penalaran dan mendemonstrasikan inkuiri ilmiah siswa. Pengertian tersebut mengindikasi suatu kompetensi yang harus dicapai, yaitu menilai kompetensi ranah psikomotor (KI-4). Kompetensi Dasar (KI-4) merupakan implementasi dari pengetahuan yang diperoleh dari KI-3 menjadi keterampilan dengan memanfaatkan lingkungan sebagai sumber belajar bagi siswa (Permendikbud, 2016). Siswa harus menuntaskan KI-3 sebelum menunjukkan kinerjanya (KI-4), KI. 3 yaitu Memahami, menerapkan, menganalisis pengetahuan faktual, konseptual, prosedural berdasarkan rasa 
ingin tahunya tentang ilmu pengetahuan, teknologi, seni, budaya, dan humaniora dengan wawasan kemanusiaan, kebangsaan, kenegaraan, dan peradaban terkait penyebab fenomena dan kejadian, serta menerapkan pengetahuan prosedural pada bidang kajian yang spesifik sesuai dengan bakat dan minatnya untuk memecahkan masalah. Penerapan Performance Based Assessment berada pada KI.4, yaitu mengolah, menalar, dan menyaji dalam ranah konkret dan ranah abstrak terkait dengan pengembangan dari yang dipelajarinya di sekolah secara mandiri, dan mampu menggunakan metoda sesuai kaidah keilmuan. Berikut adalah Kompetensi Dasar berkenaan dengan penerapan Performance Based Assessment.

\section{Implementasi Performance Based Assessment pada Pembelajaran Ekonomi}

Dalam kajian ini, penulis memilih KD. 4.3 Menyajikan hasil analisis masalah ketenagakerjaan dalam pembangunan ekonomi dan cara mengatasinya. Dalam kegiatan pembelajarannya siswa melakukan kajian tentang masalah ketenagakerjaan dalam pembangunan ekonomi dan cara mengatasinya. Indiktornya adalah (1) Siswa dapat mengumpulkan data-data dan menganalisis mengenai masalah ketenagakerjaan dalam pembangunan ekonomi dan cara mengatasinya; (2) Siswa dapat mengolah hasil analisis mengenai masalah ketenagakerjaan dalam pembangunan ekonomi dan cara mengatasinya berdasarkan data yang telah dikumpulkan; (3) Siswa dapat mempresentasikan hasil dari kajian mengenai masalah ketenagakerjaan dalam pembangunan ekonomi dan cara mengatasinya (Permendikbud, 2016).

Pada pembahasan ini, penulis merancang Performance Based Assessment dengan pendekatan inkuiri metode diskusi untuk mencapai tujuan pembelajaran yaitu siswa dapat memiliki Kemampuan menganalisis (kemampuan berpikir tinggi), dan kemampuan mengomunikasikan hasil analisis. Penulis memilih materi ketenagakerjaan karena relevan dengan tujuan pembelajaran ekonomi yaitu memiliki kemampuan membentuk sikap bijak, rasional dan bertanggungjawan dengan memiliki pengetahuan dan keterampilan ilmu ekonomi yang berguna untuk siswa dalam dunia kerja. Siswa yang memiliki pengetahuan dan keterampilan akan mampu menghadapi masalah ketenagakerjaan.

Penerapannya sebagai berikut:

\section{Tahap pertama: Merancang Pembelajaran}

Kompetensi Dasar (3.1) Menganalisis permasalahan ketenagakerjaan di Indonesia. (4.3) Menyajikan hasil analisis masalah ketenagakerjaan dalam pembangunan ekonomi dan cara mengatasinya. Indikatornya 3.1 yaitu a) mengkarateristikkan ketenagakerjaan, kesempatan kerja, tenaga kerja dan angkatan kerja; b) mendiagnosa upaya meningkatkan kualitas tenaga kerja; c) mendeskripsikan sistem upah; d) mengaitkan masalah pengangguran dengan pembangunan ekonomi; e) memecahkan masalah ketenagakerjaan dengan memberi solusi cara mengatasi masalah ketenagakerjaan. Indikator 4.3 yaitu a) mengumpulkan data-data mengenai masalah ketenagakerjaan dalam pembangunan ekonomi dan cara mengatasinya; b) membuat laporan hasil analisis masalah ketenagakerjaan dalam pembangunan ekonomi dan cara mengatasinya; c) melaporkan hasil analisis masalah ketenagakerjaan dalam pembangunan ekonomi dan cara mengatasinya. Tujuannya adalah siswa dapat mengkarateristikkan ketenagakerjaan, kesempatan kerja, tenaga kerja dan angkatan kerja, mendiagnosa upaya meningkatkan kualitas tenaga kerja, mendeskripsikan sistem upah, mengaitkan masalah pengangguran dengan pembangunan ekonomi, memecahkan masalah ketenagakerjaan dengan memberi solusi cara mengatasi masalah ketenagakerjaan, membuat dan menyajikan laporan hasil analisis serta melaporkan hasil analisis masalah ketenagakerjaan dalam pembangunan ekonomi dan cara mengatasinya.

Materi pembelajaran yaitu pengertian ketenagakerjaan, jenis-jenis tenaga kerja, masalah ketenagakerjaan, upaya meningkatkan kualitas tenaga kerja, dan sistem upah.

Penentuan tugas

1. Siswa diminta untuk membuat laporan hasil analisis yang bersumber dari artikel, buku, jurnal atau media masa. Guru akan menilai hasil makalah dengan memberi skor pada rubrik penilaian berdasarkan kualitas isi laporan hasil analisis. Pemberian tugas ini 
bertujuan untuk mengetahui kemampuan analisis dan memecahkan masalah siswa berdasarkan indikator penilaian secara tertulis.

2. Siswa mempresentasikan laporan hasil analisis yang sudah diselesaikan. Pemberian tugas ini bertujuan untuk mengetahui keterampilan siswa dalam mengomunikasikan hasil analisisnya secara lisan dengan mengaitkan kehidupan nyata (penalaran), menyatakan gagasan, dan kemampuan berdiskusi. Guru mengamati prosesnya, dengan menggunakan lembar pengamatan berupa rubrik presentasi.

3. Siswa diminta untuk mengerjakan soal essay untuk mengukur kemampuan berpikir analitis Langkah-langkah Performance Based Assessment dengan pendekatan inkuiri, sebagai berikut:

1. Guru memberi apersepsi, menjelaskan tujuan pembelajaran yang akan dicapai, memberi arahan mengenai aktivitas dalam pembelajaran yang akan dilaksanakan.

2. Siswa membentuk kelompok yang terdiri dari 4 orang yang heterogen.

3. Guru membagikan topik yang akan dikaji oleh setiap kelompok. Guru membimbing siswa dalam proses pembelajaran dan membuat laporan hasil analisis.

\section{Tahap kedua: Melaksanakan Pembelajaran}

Pada tahap ini, guru sudah menyiapkan instrumen penilaian yang dibutuhkan yaitu penilaian Written work, presentasi dan tes. Guru memberi tahu kriteria penilaian yang harus di capai oleh siswa. Hal ini bertujuan untuk memotivasi siswa untuk aktif berpartisipasi dalam pelaksanaan pembelajaran.

4. Inti

a. Mengamati (Observasi)

Siswa diminta untuk menemukan fakta bahwa terdapat hubungan antara objek yang dianalisis dengan materi pembelajaran. Siswa melakukan pengamatan berdasarkan gambar/video tentang ketenagakerjaan dan menyebutkan masalahnya berdasarkan hasil pengamatan.

b. Menanya

Setiap siswa diminta merumuskan pertanyaan mengenai ketenagakerjaan.

c. Investigasi

Siswa mengumpulkan informasi yang dibutuhkan untuk kajian literatur dari sumbersumber tertentu dan dari teman satu kelompoknya. Siswa melakukan penyelidikan sederhana untuk menemukan jawaban dari pertanyaan mereka. Siswa mencari sebanyak-banyaknya tentang informasi dan data berdasarkan topik yang akan dikaji yaitu masalah ketenagakerjaan dalam pembangunan ekonomi dan cara mengatasinya berdasarkan sumber jurnal/artikel/buku/media massa.

d. Mengasosiasi/Mengolah informasi

Siswa melakukan penalaran yaitu proses berfikir yang logis dan sistematis atas faktakata-data empiris yang dapat diobservasi untuk memperoleh simpulan berupa pengetahuan. Siswa mensintesis informasi menjadi suatu pemahaman baru bagi siswa. Siswa mulai melakukan tugas untuk membuat laporan hasil analisis. Guru membimbing siswa melakukan kegiatan, berkeliling mengamati kegiatan dan memberikan bantuan bagi kelompok yang membutuhkan.

e. Mengomunikasikan (Diskusi)

Setelah tugas selesai, siswa mengumpulkan laporan hasil analisis dan siswa dituntut untuk mengomunikasikan/mempresentasikan hasil hasil kerjanya. Siswa lainnya diminta menanggapi dan guru hanya fasilitator. (ket: Sebelum siswa menyajikan hasil analisisnya, siswa sudah melakukan konsultasi berulang kali tentang laporan). Guru melakukan penilaian kinerja.

Tahap Ketiga: Mengevaluasi pembelajaran

f. Refleksi

Guru memantapkan pemahaman siswa dengan cara mengajukan pertanyaan, disamping menganalisis cara pemecahan masalah yang dilakukan siswa. Penilaian suatu tugas dilakukan bersama-sama antara pendidik dan siswa. Artinya, kriteria yang disepakati itu 
ditunjukkan guru, tujuannya untuk siswa melakukan self assessment sehingga siswa menghayati dengan baik kekuatan dan kelemahannya. Hasil penilaian kinerja ini dijadikan tujuan baru dan sebagai tujuan memperbaiki bagi proses pembelajaran selanjutnya.

Rencana pembelajaran di atas dibuat untuk beberapa pertemuan, karena tidak bisa dilakukan dalam waktu singkat atau tidak bisa dilaksanakan dalam satu pertemuan pada setiap kegiatannya. Hal ini disebabkan oleh tugas yang berbentuk makalah sederhana yang berisi hasil analisis untuk dipresentasikan siswa.

\section{KESIMPULAN}

Pada abad ke-21 adalah abad yang meminta kualitas dalam segala usaha dan hasil kerja manusia. Guru berupaya meningkatkan kualitas pembelajaran untuk membangun individu memiliki kemampuan yang dibutuhkan pada masa sekarang dan masa akan datang. Penerapan Performance Based Assessment sebagai upaya guru untuk membangun siswa memiliki keterampilan abad 21, agar dapat mengimbangi dan menyesuaikan perubahan kondisi yang semakin kompleks dan bersaing di dunia global. Performance Based Assessment tepat diterapkan dalam pembelajaran abad 21 untuk mengembangkan output pada kompetensi-kompetensi critikal thinking atau creative thinking dan membantu siswa untuk mengembangkan beberapa keterampilan dalam memecahkan masalah.

Upaya guru dengan menerapkan Performance Based Assessment diharapkan dapat bermanfaat untuk siswa yang akan menghadapi dunia kerja, dengan tuntutan harus memiliki kemampuan menerapkan pengetahuan dan keterampilannya di dunia nyata, sumber daya manusia yang produktif, kreatif dan inovatif, individu yang menjunjung tinggi nilai-nilai etika dalam melakukan pekerjaan dan menjalin hubungan antar sesama, individu dengan kemampuan hight technology literacy, dalam rangka mewujudkan visi dan impian Indonesia 2015-2085 menuju negara yang mandiri di Asia Pasifik, menuju negara pendapatan tinggi dan salah satu PDB terbesar dunia, mencapai kemajuan dan kecepatan pertumbuhan ekonomi serta Indonesia sebagai pusat ekonomi kreatif dan digital kelas dunia. Sehingga, pembangunan sumber daya manusia dan penguasaan ilmu pengetahuan dan teknologi merupakan pilar penting untuk mewujudkan impian Indonesia 2015-2085.

Visi di atas akan tercapai jika Performance Based Assessment berhasil diterapkan oleh semua guru. Sebaiknya guru kreatif dan inovatif merencanakan tugas sesuai dengan perkembangan kognitif siswa, instruksi yang jelas dan dipahami oleh siswa, memungkinkan semua siswa untuk menunjukkan kinerjanya/produktif/aktif, guru tidak subyektif, teliti menilai siswa, memiliki alat dan data penilaian yang lengkap sehingga menjadi acuan guru meningkatkan pembelajaran guna mencapai tujuan pendidikan.

\section{REFERENSI}

Airasian, Peter W. 2005. Classroom Assessment: Concepts and Applications ( $5^{\text {th }}$ ed.). New York: McGraw Hill.

Anderson, L.W., and Krathwohl, D.R. (2001). A Taxonomy of learning, teaching, and assessing: a revision of bloom's taxonomy of eductional objectives. New york Addison Wesley Longman, In.

Anggreadi, K.Y., Santiyadnya, N.,Sutaya, I.W. 2015. Penerapan project based Learning Dengan Asesmen Autentik untuk Meningkatkan Hasil Belajar Prakarya dan Kewirausahaan Siswa Kelas X Mia 9 Sma Negeri 1 Singaraja Tahun Ajaran 2014/2015. Jurusan Pendidikan Teknik Elektro,4 (1): 74-84

Arends, Richard I. 2004. Learning to Teach (6th ed.). NewYork: McGraw Hill.

Atkin, J. M., Black, P., \& Coffey, J. (2001). Classroom assessment and the national science education standards. Washington, DC: National Academies Press.

Baker, E. L. (1997). Model-based performance assessment. Theory Into Practice, 36, 247254. 
Baron, J. B., \& Wolf, D. P. (1996). Performance-based student assessment: Challenges and possibilities. Chicago: University of Chicago.

Baxter, G., \& Glaser, R. (1996). Assessment and instruction in the science classroom (No. ). Los Angeles: Centre for Research on Evaluation Standards and Student Testing (Cresst).

Benjamin, Avis. 2014. The Impact of Performance Assessment on Students' Interest and Academic Performance in Science. Degree of Master of Education: The Univerisity of the West Indies

Brualdi, Amy C. 1998. Implementing Performance Assessment in the Classroom. Practical Assessment, Research \& Evaluation, 6(2)

Bappenas. 2017. Visi Indonesia 2045. Orasi IImiah Fakultas Ekonomi dan Ekonomi. Jakarta: Universitas Indonesia

Epstein, Andrew. (2006). Assessment the Portfolio Process. Tersedia pada http://www.teachervision.fen.com/teaching-methods/exp-educ/4537.html. Diakses pada tanggal 31 Agustus 2006

Griffith, W.I. Lim, Hye-Yeon. 2012. Performance-Based Assessment: Rubrics, Web 2.0 Tools and Language Competencies. MEXTESOL Journal, Volume 36, Number 1: 1-12

Gronlund, Norman E. (1998). Assesment of Student Achievment Sixth Edition. Boston : Allyn and Bacon.

Hibbard, K. Michael. 1999. Performance Assessment in the Classroom. New York: Mc. Graw Hill

Isa \& Burhanuddin. 2014. Penerapan Performance Assessment Untuk Menilai Kemampuan Komunikasi Matematika Siswa Pada Materi Turunan Di Sma Negeri Kota Banda Aceh Jurnal Visi IImu Pendidikan Universitas Serambi Mekkah

Istiyani, LA. 2016. Deskripsi Kemampuan Berpikir Analistis Matematika. FKIP UMP.

Johnson, R.L., Penny, J.A., \& Gordon, B. (2009). Assessing performance: designing, scoring, and validating performance task. London: The Guilford Press

Kim, K., Joyce VanTassel-Baska., Bruce A. Bracken., Annie. F., and Tamra .S. 2014. Assessing Science Reasoning and Conceptual Understanding in the Primary Grades Using Standardized and Performance Based Assessments. Journal of Advanced Academic,25 (1): 47-66

Kusmarni, Yani. 2006. Penerapan Asesmen Kinerja Dalam Pembelajaran Ips. Prosiding IPS

Lane, S. 2010. Performance Assessment: The State of the Art. SCOPE Student Performance Assessment Series. Stanford, CA: Stanford University, Stanford Center for Opportunity Policy in Education.

Lim, H-Y, \& Griffith, W.I. (2011). Practice doesn't make perfect. MEXTESOL Journal, Vol. 34 No.3

Linn, R. L., \& Gronlund, N. E. (2000). Measurement and Assessment in Teaching. Seventh Edition. Englewood Cliff: Merril, an imprint of Prentice Hall.

Linn, Robert L., Baker, Eva L., Dunbar, Stephen B. 1991. Complex, Performance-Based Assessment: Expectations and Validation Criteria. Educational Researcher American Educational Research Association. Vol. 20, No. 8, pp. 15-21

Lund J. L \& Kirk, M. F. 2010. Performance- Based Assessment for Middle and High school Physical Education. USA. Human Kinetics.

Mansur, HR. 2015. Implementasi Penilaian Autentik Kurikulum 2013 Di Sekolah Menengah Atas (Sma). Widyaiswara LPMP Provinsi Sulawesi Selatan. Artikel E-Buletin Edisi Maret ISSN. 2355-3189

Marhaeni. Pembelajaran Berbasis Asesmen Otentik Dalam Rangka Implementasi Sekolah Kategori Mandiri (SKM). Disampaikan dalam Pelatihan Peningkatan Kinerja Guru SMA 1 Kediri Tabanan, dalam Rangka Implementasi SKM; tanggal 30 Desember 2008

Marzano, R. S., Pickering, D., \& McTighe, S. (1993). Assessing student outcomes: Performance assessment using the dimensions of learning model. Alexandria, VA: Association for Supervision and Curriculum Development. 
Metin, M. \& Ozmen, H. 2010. Investigation of Teacher Opinions about Performance Assessment with Respect to the Gender and Branch Variables. Turkish Science Education, 8 (4): 3-17

Morrison, J., McDuffie, A., \& Akerson, V. (2002). A Focus for collaboration: developing and implementing Science and Mathematics performance assessment tasks. Retrieved from ERIC Document Reproduction Service No. ED465611

Muhson, Ali. 2011. Portofolio-Based Instruction Sebagai Model Pembelajaran. Jurnal Ekonomi \& Pendidikan, Volume 8 Nomor 1

Muslich, Masnur. 2011. Authentic Assessment : Penilaian Berbasis Kelas dan Kompetensi. Bandung : Refika Aditama.

Nitko, B. J. \& Brookhart, S. M. (2011). Educational assessment of student (6 ed.). Boston: Pearson Education, Inc.

Nurdin, Saiful Imam Ali. 2017. Pengembangan Performance Assessment Berbasis Inkuiri Terbimbing Untuk Mengukur Keterampilan Argumentasi Siswa. Tesis. Bandar Lampung: Universitas Lampung

Oberg, C. 2000. Guiding Classroom Instruction Through Performance Assessment. Journal of Case Studies in Accreditation and Assessment 1(1): 1-11.

.Permendikbud Nomor 24. 2016. Kompetensi Inti Dan Kompetensi Dasar Pelajaran Pada Kurikulum 2013 Pada Pendidikan Dasar Dan Pendidikan Menengah. Jakarta: Depdiknas.

Resnick, L. B., \& Resnick, D. L. (in press). Assessing the thinking curriculum: New tools for educational reform. In B. R. Gifford \& M. C. O'Connor (Eds.), Future assessments: Changing views of aptitude, achievement, and instruction.. Boston: Kluwer.

Reynolds, C.R. add.all. 2010. Measurement and Assessment in Education. USA: Pearson Education LTD.

Rothman, R. (1995). Measuring up: Standards, assessment, and school reform. San Francisco: Jossey-Bass.

Rufina. Nelson, Rosaroso. 2015. Performance-based Assessment in Selected Higher Education Institutions in Cebu City, Philippines. Asia Pacific Journal of Multidisciplinary Research, Vol. 3, No. 4, Part IV

Sa'dijah, C. 2009. Asesmen Kinerja dalam Pendidikan Matema Jurnal Pendidikan Inovatif, 4 (2): $92-95$

Segara, Nuansa Bayu. 2014. Penggunaan Rubrik Sebagai Alternative Assessment Pada Mata Kuliah Seminar Studi Sosial. Edunomic | Volume 2 No. 2.

Slavin, R.E. 2009. Psikologi Pendidikan Teori dan Prakti. Jakarta: PT Indeks.

Stiggins, R. J. 1994. Student-Centered Classroom Assessment. New York: Macmillan College Publishing Company.

Sujarwanto., Rusilowati, Ani. 2015. Pengembangan Instrumen Performance Assessment Berpendekatan Scientific Pada Tema Kalor Dan Perpindahannya. Unnes Science Education Journal, 4 (1): 780-787

Suwandi, Sarwiji. 2010. Model Assesment dalam Pembelajaran. Surakarta: Yuma Pustaka.

Suzann Schiemer. 2000. Assessment Strategies Elementary Physical Education. USA: Human kinetics.

Quiter, M. (2007). Performance Assessment. Presentation based on the optional reading by Popham. An Overview of Chapter 8, Popham, W. J. (2002). Classroom Assessment: What Teachers Need to Know. 4th ed. Boston: Allyn and Bacon.

VanTassel-Baska, J. 2014. Performance-Based Assessment The Road to Authentic Learning for the Gifted. Gifted Child Today, 37(1),41-47.

Washer, B., \& Cochran, L. 2012. Performance Assessment in CTE: Focusing on the Cognitive, Psychomotor and Affective Domains. Techniques: Connecting Education and Careers (J3), 87 (6), 30-34

Wiggins, G. 1998. Educative Assessment: Designing Assessment to Inform and Improve Student Perfromance. San Francisco: Jossey Bass 
Oikos: Jurnal Kajian Pendidikan Ekonomi dan IImu Ekonomi, ISSN Online: 2549-2284 Volume II Nomor 1, Mei 2018

Wren, Douglas G. 2009. Performance Assessment: A Key Component Of A Balanced Assessment System. Research Brief. Report From The Department Of Reseacrh Evaluation, and Assessment. No 2. Hal: 2.

Zainul, A. (2005). Alternative Assessment. Jakarta: Dirjen Dikti. 


\section{Lampiran}

Contoh rubrik penilaian laporan

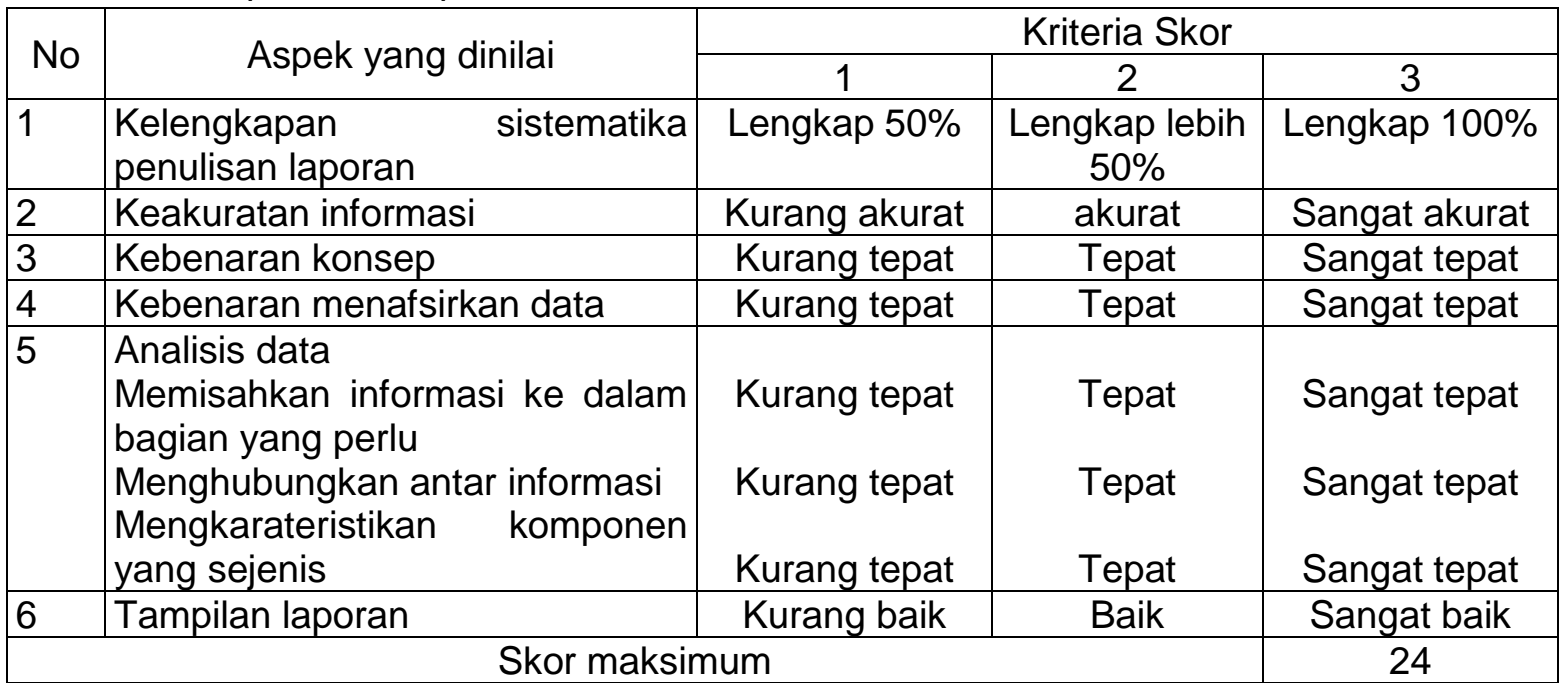

Sumber: Diadaptasi dari Mansur (2015) pada artikel E-Buletin

Contoh rubrik penilaian presentasi

\begin{tabular}{|c|c|c|c|c|}
\hline \multirow{2}{*}{ Kriteria } & \multicolumn{4}{|c|}{ Level kompetensi } \\
\hline & 4 & 3 & 2 & 1 \\
\hline Materi & $\begin{array}{l}\text { Siswa mampu } \\
\text { menjelaskan } \\
\text { keseluruhan materi } \\
\text { tanpa melihat } \\
\text { catatan }\end{array}$ & \begin{tabular}{|l|} 
Siswa mampu \\
menjelaskan \\
keseluruhan materi \\
dengan sesekali \\
melihat catatan
\end{tabular} & \begin{tabular}{|l|} 
Siswa mampu \\
menjelaskan \\
keseluruhan materi \\
dengan sering \\
melihat catatan
\end{tabular} & $\begin{array}{l}\text { Siswa mampu } \\
\text { menjelaskan } \\
\text { keseluruhan } \\
\text { materi dengan } \\
\text { selalu melihat } \\
\text { catatan }\end{array}$ \\
\hline Efektivitas & $\begin{array}{l}\text { Menjelaskan } \\
\text { materi secara } \\
\text { sistematis, tepat } \\
\text { sasaran, terarah } \\
\text { dan tidak berbelit- } \\
\text { belit }\end{array}$ & $\begin{array}{l}\text { Menjelaskan } \\
\text { materi secara } \\
\text { sistematis, dan } \\
\text { tidak berbelit-belit }\end{array}$ & $\begin{array}{l}\text { Menjelaskan } \\
\text { materi secara } \\
\text { sistematis, namun } \\
\text { berbelit-belit }\end{array}$ & $\begin{array}{l}\text { Menjelaskan } \\
\text { materi tidak } \\
\text { sistematis, dan } \\
\text { tidak sangat } \\
\text { berbelit-belit }\end{array}$ \\
\hline Kreativitas & $\begin{array}{l}\text { Terampil dan } \\
\text { memahami grafik/ } \\
\text { gambar/ } \\
\text { digram/bagan } \\
\text { dalam } \\
\text { menyampaikan } \\
\text { materi }\end{array}$ & $\begin{array}{l}\text { Terampil dan } \\
\text { memahami grafik/ } \\
\text { gambar/ } \\
\text { digram/bagan } \\
\text { dalam } \\
\text { menyampaikan } \\
\text { materi namun } \\
\text { terdapat kesalahan }\end{array}$ & $\begin{array}{l}\text { Tidak terampil dan } \\
\text { memahami grafik/ } \\
\text { gambar/ } \\
\text { digram/bagan } \\
\text { dalam } \\
\text { menyampaikan } \\
\text { materi }\end{array}$ & $\begin{array}{l}\text { Tidak } \\
\text { menggunakan } \\
\text { grafik/gambar/ } \\
\text { digram/bagan } \\
\text { dalam } \\
\text { menyampaikan } \\
\text { materi }\end{array}$ \\
\hline Kontak mata & $\begin{array}{l}\text { Berdiri tegak, rileks } \\
\text { dan percaya diri. } \\
\text { menatap ke semua } \\
\text { orang selama } \\
\text { presentasi }\end{array}$ & $\begin{array}{l}\text { Berdiri tegak dan } \\
\text { menatap ke semua } \\
\text { orang di kelas } \\
\text { selama presentasi }\end{array}$ & $\begin{array}{l}\text { Kadang berdiri } \\
\text { tegak, sesekali } \\
\text { menatap ke } \\
\text { sebagian orang di } \\
\text { kelas selama } \\
\text { presentasi }\end{array}$ & $\begin{array}{l}\text { Tertunduk dan } \\
\text { tidak mampu } \\
\text { menatap ke } \\
\text { orang selama } \\
\text { presentasi }\end{array}$ \\
\hline & $\begin{array}{l}\text { Berbicara dengan } \\
\text { jelas }(100 \%-95 \%)\end{array}$ & $\begin{array}{l}\text { Berbicara dengan } \\
\text { jelas }(100 \%-95 \%)\end{array}$ & $\begin{array}{l}\text { Berbicara dengan } \\
\text { jelas }(94 \%-85 \%)\end{array}$ & $\begin{array}{l}\text { Berbicara } \\
\text { jelas dan }\end{array}$ \\
\hline
\end{tabular}




\begin{tabular}{|c|c|c|c|c|}
\hline & $\begin{array}{l}\text { selama presentasi } \\
\text { dan tidak ada } \\
\text { salah kata }\end{array}$ & $\begin{array}{l}\text { selama presentasi } \\
\text { dan beberapa } \\
\text { salah kata }\end{array}$ & $\begin{array}{l}\text { selama presentasi } \\
\text { dan sering salah } \\
\text { kata }\end{array}$ & $\begin{array}{l}\text { dimengerti } \\
\text { selama } \\
\text { presentasi }\end{array}$ \\
\hline $\begin{array}{l}\text { Penggunaan } \\
\text { teknologi }\end{array}$ & $\begin{array}{l}\text { Mampu dengan } \\
\text { tenang, tidak kaku } \\
\text { dan terampil tanpa } \\
\text { ada kesalahan } \\
\text { dalam } \\
\text { menggunakan } \\
\text { aplikasi/ perangkat } \\
\text { untuk presentasi. }\end{array}$ & \begin{tabular}{|l} 
Mampu dengan \\
tenang, tidak kaku \\
dan terampil \\
namun masih \\
melakukan \\
kesalahan \\
dalam \\
menggunakan \\
aplikasi/perangkat \\
untuk presentasi.
\end{tabular} & $\begin{array}{l}\text { Masih kaku, tidak } \\
\text { tenang dalam } \\
\text { menggunakan } \\
\text { aplikasi/perangkat } \\
\text { untuk presentasi. }\end{array}$ & $\begin{array}{l}\text { Tidak } \\
\text { menggunakan } \\
\text { aplikasi/perang } \\
\text { kat } \\
\text { untuk } \\
\text { presentasi. }\end{array}$ \\
\hline Bahasa & $\begin{array}{l}\text { Menggunakan } \\
\text { Bahasa Indonesia } \\
\text { formal yang baik } \\
\text { dan } \\
\text { benar selama } \\
\text { presentasi tanpa } \\
\text { kesalahan. }\end{array}$ & \begin{tabular}{|l|} 
Menggunakan \\
Bahasa \\
Indonesia formal \\
yang baik dan \\
benar selama \\
presentasi dengan \\
beberapa \\
kesalahan. \\
\end{tabular} & \begin{tabular}{|l} 
Menggunakan \\
Bahasa Indonesia \\
formal yang baik \\
dan benar selama \\
presentasi dengan \\
banyak kesalahan.
\end{tabular} & $\begin{array}{l}\text { Menggunakan } \\
\text { Bahasa } \\
\text { Indonesia } \\
\text { pergaulan } \\
\text { yang kurang } \\
\text { tepat } \\
\text { selama } \\
\text { presentasi. }\end{array}$ \\
\hline Volume & $\begin{array}{l}\text { Volume cukup } \\
\text { untuk terdengar ke } \\
\text { semua audience } \\
\text { atau } \\
\text { ruangan kelas. }\end{array}$ & $\begin{array}{l}\text { Volume cukup } \\
\text { keras untuk } \\
\text { didengar } 90 \% \\
\text { audiance. }\end{array}$ & $\begin{array}{l}\text { Volume cukup } \\
\text { untuk terdengar } \\
\text { dari } 75 \% \\
\text { audience. }\end{array}$ & $\begin{array}{l}\text { Suara tidak } \\
\text { terdengar } \\
\text { jelas selama } \\
\text { presentasi. }\end{array}$ \\
\hline Menjawab & $\begin{array}{l}\text { Menjawab dengan } \\
\text { akurat semua } \\
\text { pertanyaan yang } \\
\text { diberikan oleh } \\
\text { teman kelasnya. }\end{array}$ & \begin{tabular}{|l|} 
Menjawab dengan \\
akurat sebagaian \\
besar \\
pertanyaan yang \\
diberikan oleh \\
teman kelasnya.
\end{tabular} & $\begin{array}{l}\text { Menjawab dengan } \\
\text { akurat sedikit } \\
\text { pertanyaan yang } \\
\text { diberikan oleh } \\
\text { teman kelasnya. }\end{array}$ & $\begin{array}{l}\text { Tidak } \\
\text { Menjawab } \\
\text { dengan akurat } \\
\text { semua } \\
\text { pertanyaan } \\
\text { yang diberikan } \\
\text { oleh teman } \\
\text { kelasnya. }\end{array}$ \\
\hline Kerjasama & $\begin{array}{l}\text { siswa bertemu } \\
\text { dan berdiskusi } \\
\text { secara berkala. } \\
\text { Seluruh siswa } \\
\text { berkontribusi } \\
\text { dalam diskusi dan } \\
\text { mendengarkan } \\
\text { dengan penuh } \\
\text { perhatian. }\end{array}$ & $\begin{array}{l}\text { siswa bertemu } \\
\text { dan berdiskusi } \\
\text { secara berkala. } \\
\text { Sebagian besar } \\
\text { siswa berkontribusi } \\
\text { dalam diskusi dan } \\
\text { mendengarkan } \\
\text { dengan penuh } \\
\text { perhatian. }\end{array}$ & $\begin{array}{l}\text { Beberapa dari } \\
\text { grup mengadakan } \\
\text { pertemuan. } \\
\text { Sebagaian besar } \\
\text { siswa } \\
\text { berkontribusi untuk } \\
\text { berdiskusi dan } \\
\text { mendengarkan } \\
\text { dengan perhatian }\end{array}$ & $\begin{array}{l}\text { Tidak pernah } \\
\text { ada } \\
\text { pertemuan dan } \\
\text { diskusi. }\end{array}$ \\
\hline
\end{tabular}

Sumber: diadaptasi dari Segara (2014), Edunomic

Contoh rubrik penilaian kemampuan berpikir analitis (tes tertulis)

\begin{tabular}{|l|l|l|l|l|}
\hline Indikator & \multicolumn{4}{|c|}{ Rating } \\
\cline { 2 - 5 } & Tidak memenuhi & Memenuhi & Memenuhi & Memenuhi \\
& standar $(25 \%$ & standar minimal & standar $(75 \%$ & standar mksimal \\
& dari & (50\% dari & dari deskriptor $=$ & $(100 \%$ dari \\
& deskriptor=1) & deskriptor=2 & $3)$ & deskriptor=4) \\
\hline
\end{tabular}


Oikos: Jurnal Kajian Pendidikan Ekonomi dan IImu Ekonomi, ISSN Online: 2549-2284

Volume II Nomor 1, Mei 2018

\begin{tabular}{|c|c|c|c|c|}
\hline $\begin{array}{l}\text { siswa } \\
\text { membedakan } \\
\text { bagian yang } \\
\text { tidak relevan } \\
\text { dan yang } \\
\text { relevan dari } \\
\text { suatu materi }\end{array}$ & $\begin{array}{l}\text { siswa tidak } \\
\text { mampu } \\
\text { membedakan } \\
\text { bagian yang } \\
\text { tidak relevan } \\
\text { dan yang } \\
\text { relevan dari } \\
\text { suatu materi }\end{array}$ & $\begin{array}{l}\text { siswa memiliki } \\
\text { kemampuan } \\
\text { sangat minim } \\
\text { dalam } \\
\text { membedakan } \\
\text { bagian yang } \\
\text { tidak relevan } \\
\text { dan yang } \\
\text { relevan dari } \\
\text { suatu materi }\end{array}$ & $\begin{array}{l}\text { siswa mampu } \\
\text { membedakan } \\
\text { bagian yang } \\
\text { tidak relevan } \\
\text { dan yang } \\
\text { relevan dari } \\
\text { suatu materi }\end{array}$ & $\begin{array}{l}\text { siswa mampu } \\
\text { membedakan } \\
\text { bagian yang } \\
\text { tidak relevan } \\
\text { dan yang } \\
\text { relevan dari } \\
\text { suatu materi } \\
\text { secara } \\
\text { sempurna }\end{array}$ \\
\hline $\begin{array}{l}\text { Siswa } \\
\text { menentukan } \\
\text { bagaimana } \\
\text { suatu bagian } \\
\text { elemen tersebut } \\
\text { cocok dan dapat } \\
\text { berfungsi } \\
\text { bersama-sama } \\
\text { di dalam suatu } \\
\text { struktur }\end{array}$ & $\begin{array}{l}\text { Siswa tidak } \\
\text { mampu } \\
\text { menentukan } \\
\text { bagaimana } \\
\text { suatu bagian } \\
\text { elemen tersebut } \\
\text { cocok dan dapat } \\
\text { berfungsi } \\
\text { bersama-sama } \\
\text { di dalam suatu } \\
\text { struktur }\end{array}$ & $\begin{array}{l}\text { Siswa memiliki } \\
\text { kemampuan } \\
\text { sangat minim } \\
\text { dalam } \\
\text { menentukan } \\
\text { bagaimana } \\
\text { suatu bagian } \\
\text { elemen tersebut } \\
\text { cocok dan dapat } \\
\text { berfungsi } \\
\text { bersama-sama } \\
\text { di dalam suatu } \\
\text { struktur }\end{array}$ & $\begin{array}{l}\text { Siswa mampu } \\
\text { menentukan } \\
\text { bagaimana } \\
\text { suatu bagian } \\
\text { elemen tersebut } \\
\text { cocok dan dapat } \\
\text { berfungsi } \\
\text { bersama-sama } \\
\text { di dalam suatu } \\
\text { struktur }\end{array}$ & $\begin{array}{l}\text { Siswa mampu } \\
\text { menentukan } \\
\text { bagaimana } \\
\text { suatu bagian } \\
\text { elemen tersebut } \\
\text { cocok dan dapat } \\
\text { berfungsi } \\
\text { bersama-sama } \\
\text { di dalam suatu } \\
\text { struktur secara } \\
\text { sempurna }\end{array}$ \\
\hline $\begin{array}{l}\text { Siswa } \\
\text { menghubungkan } \\
\text { inti dari suatu } \\
\text { materi }\end{array}$ & $\begin{array}{l}\text { Siswa tidak } \\
\text { mampu } \\
\text { menghubungkan } \\
\text { inti dari suatu } \\
\text { materi }\end{array}$ & $\begin{array}{l}\text { Siswa memiliki } \\
\text { kemampuan } \\
\text { sangat minim } \\
\text { menghubungkan } \\
\text { inti dari suatu } \\
\text { materi }\end{array}$ & $\begin{array}{l}\text { Siswa mampu } \\
\text { menghubungkan } \\
\text { inti dari suatu } \\
\text { materi }\end{array}$ & $\begin{array}{l}\text { Siswa mampu } \\
\text { menghubungkan } \\
\text { inti dari suatu } \\
\text { materi secara } \\
\text { sempurna }\end{array}$ \\
\hline
\end{tabular}

Sumber: diadaptasi dari Istiyani (2016) 